\title{
Elektrosztatikus szálképzéssel előállított amorf szilárd diszperzió feldolgozhatóságának vizsgálata
}

\author{
DÉMUTH Balázs* \\ Budapesti Müszaki és Gazdaságtudományi Egyetem, Szerves Kémia és Technológia Tanszék, \\ 1111 Budapest, Müegyetem rakpart 3.
}

\section{Bevezetés}

Korunk gyógyszeripara több kihívás előtt áll. Az elmúlt évtizedek egyik legfontosabb változása a rossz vízoldhatóságú hatóanyagok megsokszorozódása a kutatás és fejlesztésben, mely több okra vezethető vissza (pl.: nagy áteresztőképességü szürés). Ezzel párhuzamosan az újonnan felfedezett (originális) hatóanyagok száma folyamatosan esik vissza. E két ok következtében a gyógyszertechnológiai, készítményfejlesztési kutatások jelentősége erőteljesen növekszik.

Egyes elemzések szerint a jelenleg forgalomban levő gyógyszerek 40\%-a rossz vízoldhatóságú (Biofarmáciai Osztályozási Rendszer II-es és IV-es osztálya), míg az új hatóanyagok esetén ez a szám 70\% (oldhatóság <100 $\mu \mathrm{g} / \mathrm{l}$ ). A rossz vízoldhatóság sokszor gyenge biohasznosulást eredményez, így kritikusnak tekinthető az oldhatóság/ kioldódás növelése. Az alacsony biohasznosulás akár egy biológiailag aktív, értékes hatóanyag gyógyszerként történő forgalomba hozatalát is megakadályozhatja.

Természetesen több féle megoldás került kidolgozásra az évek során a kioldódás növelésére, mint például só képzés, származékképzés, részecskeméret csökkentése vagy komplexálás. Az egyik legbiztatóbb útnak tűnik az amorf szilárd diszperziók (ASD-k) előállítása. ASD-nak egy vagy több hatóanyag inert hordozós vagy mátrixos diszperzióját tekintjük. Többféle diszperziót lehet elöállítani a hatóanyag(ok) és a mátrix fizikai állapota alapján, azonban gyógyszertechnológiai szempontból a legfontosabbnak az amorf polimerben molekulárisan eloszlatott amorf hatóanyag diszperziója vehető. Mindig kulcskérdés az amorf hatóanyag fizikai stabilitása, ti. kristályosodás esetén az ASD elveszíti előnyös tulajdonságait.

Amorf szilárd diszperzió különféle módszerekkel állítható elő, melyek közül a legelterjedtebb a porlasztva szárítás és az olvadék extrúzió. Majdnem az összes piacon levő, amorf szilárd diszperziós készítmény előállítása során e kettő technológia közül az egyiket használják fel. Az elektrosztatikus szálképzés (ES) (és egyéb szálképzési technológiák) a gyógyszeripar számára még ismeretlen ASD előállítási technológia, azonban több szempontból is előnyösebbnek tünik, mint az előzőleg említett másik kettő módszer. Elektrosztatikus szálképzés során egy hatóanyag és egy polimer oldatát pumpáljuk egy nagyfeszültségre kapcsolt porlasztófejbe. A nagyfeszültség hatására indul meg a szálképződés, és az előállított szálakat egy földelt gyüjtőlemezen gyüjtjük. Azonban az elektrosztatikus szálképzés méretnövelése illetve a keletkezett szálak végleges gyógyszerformává (praktikusan filmbevont tablettává) való alakítása még nem megoldott a gyógyszeriparban.

\section{Célkitüzés}

A kutatás fó célja, hogy az elektrosztatikus szálképzés és a szálképzett amorf szilárd diszperziók gyógyszeripari alkalmazhatóságát állapítsuk meg. Ezt követve, három fó részre bontható a kutatás:

1. Elektrosztatikus szálképzés méretnövelése, méretnövelt technológiával nyert termékek karakterizálása (összehasonlítása kisméretü, egytüs szálképzéssel kapott szilárd diszperziókkal), rövid- és hosszú távú stabilitás vizsgálata.

2. Szálképzett anyagok azonnali kioldódású, filmbevont tablettává alakítása, végleges gyógyszerformulában stabilitás vizsgálata.

3. Szálképzett anyagok segédanyagokkal való inkompatibilitásának vizsgálata, elsősorban a kioldódás szempontjából.

Jelen közleményben itrakonazol (ITR, széles spektrumú gombaölő, Biofarmáciai Osztályozási Rendszer II-es osztálya, $1 \mathrm{ng} / \mathrm{ml}$ oldhatóság vízben) és vinilpirrolidonvinilacetát-kopolimer (PVPVA64) 40-60\% összetételü ASD-jával kapcsolatos vizsgálódások kerülnek bemutatásra. Célunk volt, hogy az ITR-t, mint rendkívül rossz vízoldhatóssággal bíró hatóanyagot egy fizikailag és kémiailag is stabil, azonnali és jó kioldódású készítménybe formuláljuk.

\section{Nagysebességú elektrosztatikus szálképzés}

Az elektrosztatikus szálképzés gyógyszeripari alkalmazhatóságának egyik akadálya, hogy méretnövelt technológia, mely kielégítené az ipari igényeket, még nem áll rendelkezésre. Ez a terület aktívan vizsgált az irodalomban. A kutatócsoportunk által kifejlesztett nagy sebességü elektrosztatikus szálképzés alkalmasnak tünik a korábban említett igények kielégítésére. A technológiai paraméterek összehasonlítása (nagy sebességü szálképzés, egytüs szálképzés, filmöntés és porlasztva szárítás) az . táblázatban látható.

\footnotetext{
* Email: demuth@oct.bme.hu, Tel.: +3614631055. Jelen közlemény Démuth Balázs PhD munkája és az ahhoz kapcsolódó közlemények alapján készült.
} 
1. táblázat: ASD előállítási technológiák paramétereinek összehasonlítása

\begin{tabular}{ccccc}
\hline Technológia & $\begin{array}{c}10 \mathrm{ml} \text { oldószerben feloldott } \\
\text { szilárd anyag }(\mathrm{g})\end{array}$ & Oldószer & $\begin{array}{c}\text { Adagolási } \\
\text { sebesség }(\mathrm{ml} / \mathrm{h})\end{array}$ & $\begin{array}{c}\text { Termelékenység } \\
(\mathrm{g} / \mathrm{h})\end{array}$ \\
\hline Egytüs ES & 3,75 & $\mathrm{CH}_{2} \mathrm{Cl}_{2}+\mathrm{EtOH}(2: 1)$ & 20 & 6 \\
Nagysebességü ES & 3,75 & $\mathrm{CH}_{2} \mathrm{Cl}_{2}+\mathrm{EtOH}(2: 1)$ & 1500 & 450 \\
Filmöntés & 3,75 & $\mathrm{CH}_{2} \mathrm{Cl}_{2}+\mathrm{EtOH}(2: 1)$ & - & - \\
Porlasztva szárítás & 0,5 & $\mathrm{CH}_{2} \mathrm{Cl}_{2}+\mathrm{EtOH}(2: 1)$ & 150 & 7,5 \\
\hline
\end{tabular}

A táblázatból egyértelmüen kivehető a szálképzés két legnagyobb előnye a porlasztva szárításhoz képest: a nagyobb termelékenység és a kisebb oldószer felhasználás. A nagysebességủ elektrosztatikus szálképzés során a centrifugális erőt is kihasználjuk a szálak képzésére, nyúlására (az elektrosztatikus erő mellett), így növekedhet a termelékenység. A szálképzés egy nagy sebességgel (10000-40000 1/perc) forgó fejjel valósul meg, melyen furatok találhatók. Fontos megjegyezni, hogy a kapott szálak átméróje a szubmikronos tartományba tartozik, így azok fajlagos felülete igen nagy. Ez kiütközik a kioldódásban is, a szálas ASD-ból jóval gyorsabban szabadul fel a hatóanyag, mint a porlasztva szárított szemcsékből (1. ábra).

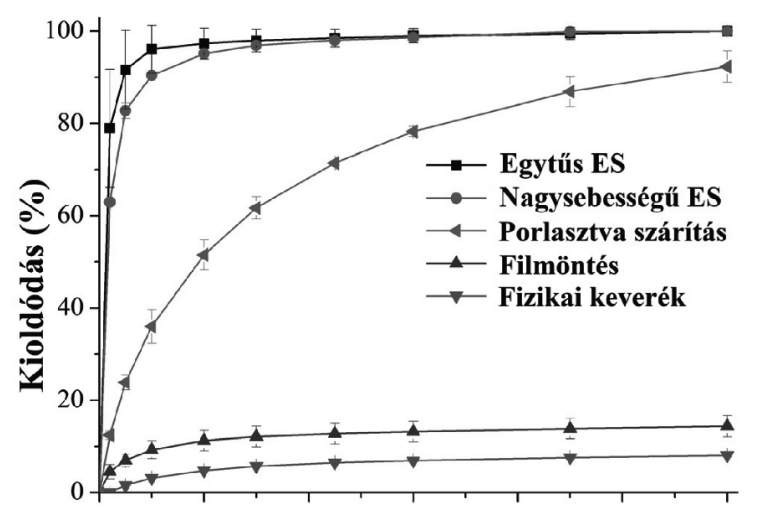

1. ábra: Különböző technológiákkal gyártott ASDk

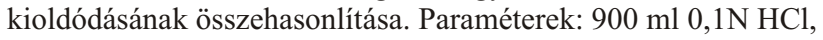
„ütögetett kosár" módszer, $37 \pm 0.5^{\circ} \mathrm{C}, 50 \mathrm{mg}$ dózis, $50 \mathrm{rpm}$ forgási sebesség.

Ezt a kristályos formáénál kedvezőbb kioldódást az egy évig, $25^{\circ} \mathrm{C}$ és $60 \%$ relatív páratartalmon tárolt anyag is fenn tudta tartani, ahogy azt a 2. ábra illusztrálja.

A kioldódás alapján az elóállított szálakban az amorf ITR tehát még igen magas tartalom (40\%) esetén se kezdett el kristályosodni, ahogy azt a differenciális pásztázó kalorimetriás és a por-röntgendiffrakciós vizsgálatok is megerősítik (további adatok, ábrák a hivatkozásban).

\section{Szálképzett ASD filmbevont tablettává alakítása}

A tablettázási kísérletek előtt a szálképzett anyagot átnyomtuk 0,8 mm-es kézi szitán, hogy segédanyagokkal

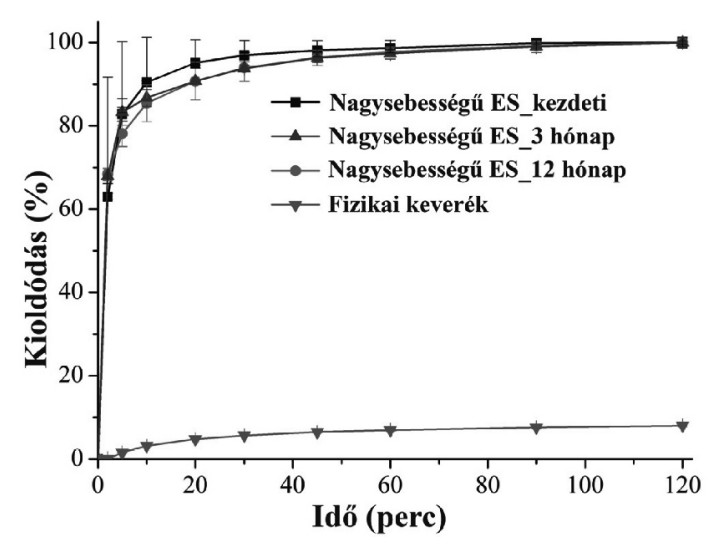

2. ábra: Nagysebességű szálképzéssel nyert ASD stabilitása kioldódás vizsgálattal. Paraméterek: 1sd. 1. ábra.

való összekeverésre alkalmas legyen. A tablettázási lépés szisztematikus vizsgálatára a gyógyszeripari trendeknek megfelelően optimalizáló kísérlettervezést $\left(2^{3}\right.$ teljes faktoriális terv) végeztünk el. Független változóknak a préserőt és az ASD/töltőanyag arányt (más összetételü keverékek), míg függő változóknak pedig a szétesési időt és a szakítószilárdságot választottuk. Felhasznált segédanyagok: mikrokristályos cellulóz, mannit, kroszpovidon, kolloidális szilícium-dioxid és magnéziumsztearát (MgSt)/nátrium-sztearil-fumarát $\quad(\mathrm{SSF}) . \quad \mathrm{Az}$ optimalizálás sikeresnek tekinthető, lehetséges volt megfelelő tabletták elóállítása kis szétesési idővel ( $\sim 5$ perc, a nagy polimer tartalom ellenére is) és nagy szakítószilárdsággal $\left(\sim 2 \mathrm{~N} / \mathrm{mm}^{2}\right)$. További információ a kísérlettervezésről a -es hivatkozásban található meg. Az optimalizált összetétellel körforgós tablettázást is kiviteleztünk, melynek során megfelelő tömegszórású, szilárdságú és szétesési idejű tablettákat sikerült elóállítani. Később részletezett okok miatt itt már nátriumsztearil-fumarát (SSF) lubrikánst (1,5\%) alkalmaztunk. Az ASD szálas szerkezete tabletta formában is megmarad, ezáltal a jó kioldódás is fenntartható. Hosszú távú (egy éves) stabilitási teszteknek $\left(25^{\circ} \mathrm{C} / 60 \%\right.$ rel. páratart.) alávetve az így kapott tablettákat, azt figyelhettük meg, hogy a szálképzett anyag fizikailag (kioldódási profil nem változik, azaz nem kristályosodik az anyag, 3. ábra) és kémiailag (jelentős bomlás nem történik, 2. táblázat) is stabil maradt. 


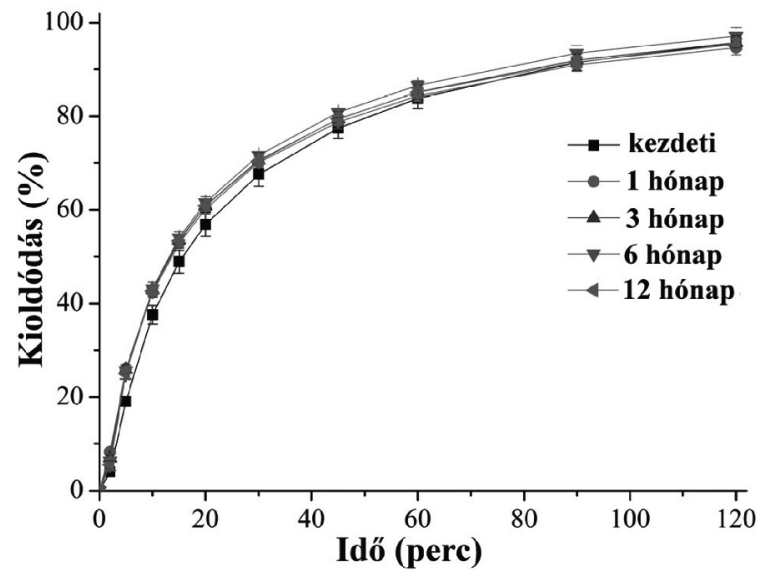

3. ábra: Szálképzett ASD-t tartalmazó, körforgós tablettázógéppel gyártott tabletták kioldódás profilja és hosszú távú stabilitás tesztje.

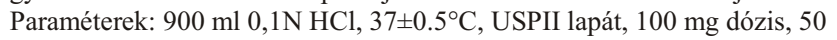
rpm forgási sebesség.

2. táblázat: Kristályos ITR és egy évig tárolt $\left(25^{\circ} \mathrm{C} / 60 \%\right.$ rel. páratart.) tabletta szennyező-tartalma

\begin{tabular}{cc}
\hline Anyag & $\%$ szennyezó \\
\hline krist. ITR & $0,46 \pm 0,02 \%$ \\
\hline 1 éves tabletta & $0,54 \pm 0,02 \%$ \\
\hline
\end{tabular}

Az ASD tartalmú tabletták filmbevonása kritikus lépésnek tekinthető, mivel vizes oldatot porlasztunk a tablettákra és azokat hőhatás is éri. A víz, mint lágyító, csökkenti az ASD üvegesedési hőmérsékletét és ezáltal negatívan befolyásolhatja a stabilitást. A megemelt hőmérsékletnek hasonló hatása van, elősegítheti az amorf hatóanyag kristályosodását. A szálképzett anyagot tartalmazó tabletták filmbevonása (Opadry ${ }^{\circledR}$ II, vizes szuszpenzió, körülbelül 3 $\mathrm{m} / \mathrm{m} \%$ bevonat) nem csökkentette a felszabaduló hatóanyag mennyiségét (4. ábra), így a folyamat sikeres volt.

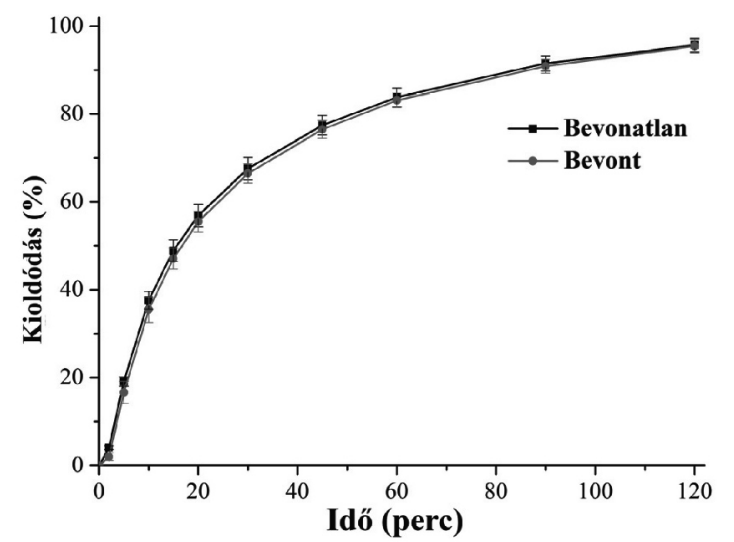

4. ábra: Bevonatlan és bevont tabletták kioldódási profilja. Paraméterek: 1sd. 3. ábra.
Ha megvizsgáljuk a kísérlettervezésből származó tabletták kioldódási profilját, egy 15-25\%-os csökkenést vehetünk észre a feloldódott mennyiségben a tiszta ASD-hoz képest, mely független a préserőtől és az összetételtől (5. ábra). Fontos megjegyezni, hogy ezen tabletták MgSt lubrikánst tartalmaztak.

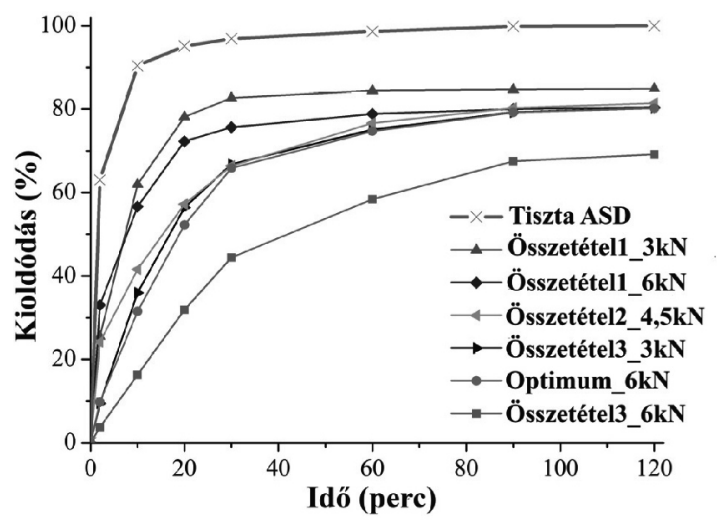

5. ábra: Tiszta szálképzett ASD és ezen ASD-t tartalmazó, különböző paraméterekkel előállított tabletták kioldódási profilja. Kioldódási paraméterek: 1sd. 3. ábra

Érdekes módon, a tablettákból minden dózisszinten $(25,50$ és $100 \mathrm{mg}$ ) nagyságrendileg hasonló százalékban oldódott fel az ITR. Érdemes megjegyezni, hogy $100 \mathrm{mg}$ hatóanyagot tartalmazó tiszta szálas anyag esetén is maximális kioldódást figyeltünk meg (6. ábra).

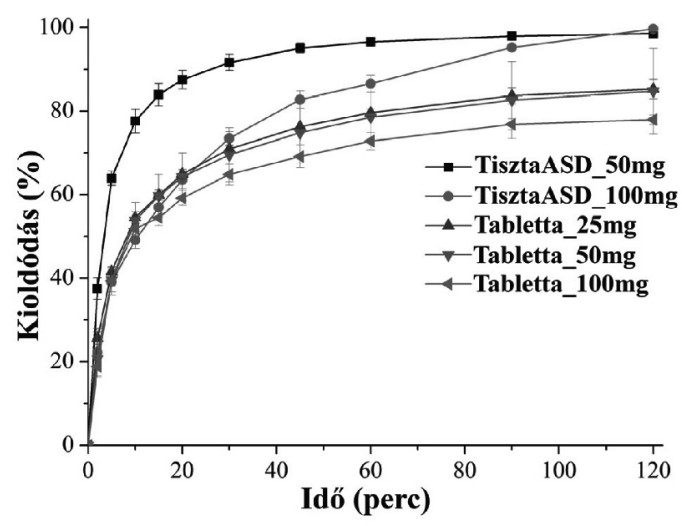

6. ábra: Tiszta ASD illetve MgSt tartalmú tabletták kioldódásának dózisfüggése. Paraméterek: 1sd. 1. és 3. ábra.

További vizsgálódások során arra a következtetésre lehet jutni, hogy a lubrikánsként (csúsztatóanyagként, frikciók enyhítésére alkalmazott segédanyag) alkalmazott MgSt csökkentette a kioldódást. A MgSt mennyisége és a kioldódás között egyértelmü kapcsolatot lehet felfedezni. Ha azonban a lubrikánst lecseréljük SSF-ra (1,5\%), 95\% feletti kioldódást tudunk elérni, mind 50 mind 100 mg-os dózis esetén (7. ábra). A lubrikáns cseréjével a préselési tulajdonságok nem romlottak le. 


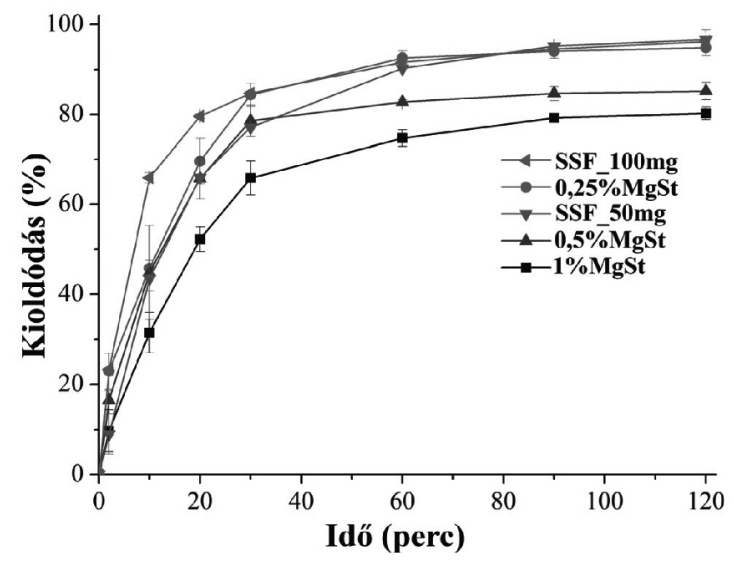

7. ábra: Különböző lubrikánssal előállított, ASD-tartalmú tabletták kioldódási profilja. Paraméterek: 1sd. 3. ábra.

Annak megállapítására, hogy pontosan mi játszódik le e jelenség során, egy különleges kioldódás elvégzése volt szükséges. E kioldódás esetén a vizsgált tabletták csak ASD-t, mannitot és MgSt-ot tartalmaztak és ezekkel végeztük el a kísérletet. A kioldódás során keletkező szilárd anyagot leszürtük, levegőn hagytuk megszáradni, majd többféle módon karakterizáltuk.

A mágneses magrezonancia spektroszkópiai vizsgálat kimutatta, hogy a szürlet ITR-t és „sztearát-láncot” tartalmaz, méghozzá 1:1 arányban (8. ábra). Energia diszperzív és atomabszorpciós spektroszkópiai vizsgálatoknak alávetve a mintát, annak magnézium tartalma közel 0-nak adódott (0,0113\%), tehát a minta magnéziumtól mentes. Következésképp, a minta ITR és sztearinsav 1:1 arányú adduktja lehet.



8. ábra: ITR és a szürlet nukleáris magrezonancia spektroszkópiás spektruma (500 MHz, CDCl3). A, B és C jelöli a "sztearát-lánchoz" tartozó csúcsokat.
Valószínűsíthetően a MgSt-ból savas közegben $(\mathrm{pH}=1,2)$ képződő sztearinsavval képzi ezt az adduktot a hatóanyag. Érdekes módon a különböző hőmérsékleten, savas $(\mathrm{pH}=1,2)$ közegben kevertetett tablettákból különbözö mennyiségü ITR oldódik fel (. táblázat). Elképzelhető, hogy a sztearinsav oldhatósága fogja befolyásolni mekkora ITR koncentrációt fogunk észlelni.

3. táblázat: ASD-tartalmú tablettákból különböző hőmérsékleteken feloldódott ITR mennyisége savas közegben.

\begin{tabular}{ccccc}
\hline $\begin{array}{c}\text { Hómérséklet } \\
\left({ }^{\circ} \mathbf{C}\right)\end{array}$ & $\sim 22$ & $\sim 32$ & $\sim 37$ & $\sim 45$ \\
\hline $\begin{array}{c}\text { Feloldódott } \\
\text { mennyiség (\%) }\end{array}$ & $101 \pm 1.5$ & $96 \pm 0.9$ & $91 \pm 1.3$ & $77 \pm 2.4$ \\
\hline
\end{tabular}

Egyéb analitikai módszereket is felhasználtunk a szürlet karakterizálására. Referencia céllal sztearinsavat is előállítottunk MgSt savas közegben való kevertetésével. A szürlet por-röntgendiffrakciós felvételén a piros téglalappal jelölt csúcsok a sztearinsavval azonosíthatók, míg a legnagyobb csúcs $17^{\circ}$-nál az ITR-hoz asszignálható, de jelentős különbségek vannak a kiindulási anyagokhoz képest. Látható a diffraktogramon, hogy a kristályos ITR-hoz képest a szürt anyag kisebb kristályossággal bír, fizikai állapota különbözik (9. ábra).

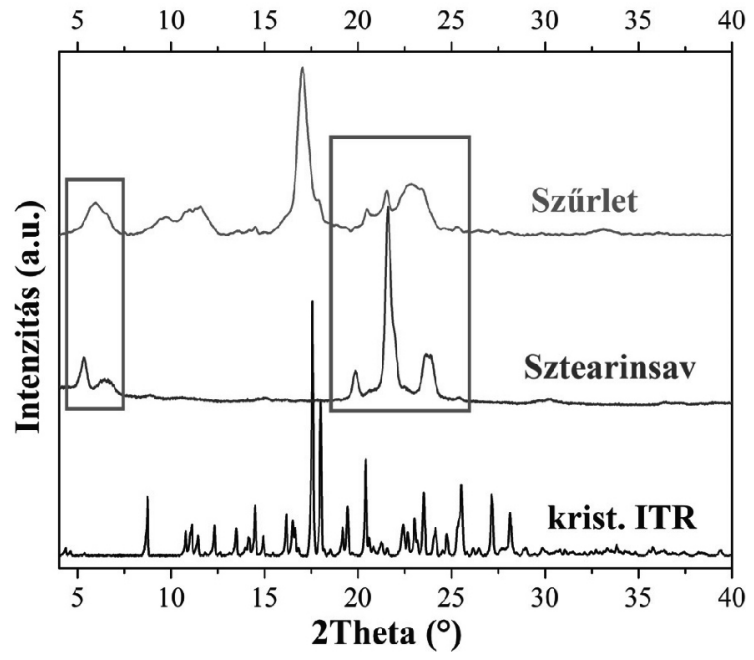

9. ábra: Kristályos ITR, sztearinsav és a szürlet röntgendiffraktogramja.

Raman-térképezést is végeztünk, hogy megvizsgáljuk a szürlet kémiai jellegét és homogenitását. A szürlet spektruma, mely elég egységes volt a térképen, hasonlít az ITR spektrumához, azonban néhány csúcs se a hatóanyaghoz, se a sztearinsavhoz nem köthető (példák a spektrumon jelölve piros téglalappal) (10. ábra). Ezen csúcsok megjelenése vagy felerösödése egy újonnan kialakult kölcsönhatásból, praktikusan az ITR és sztearinsav között kialakuló kölcsönhatásból származhatnak. 


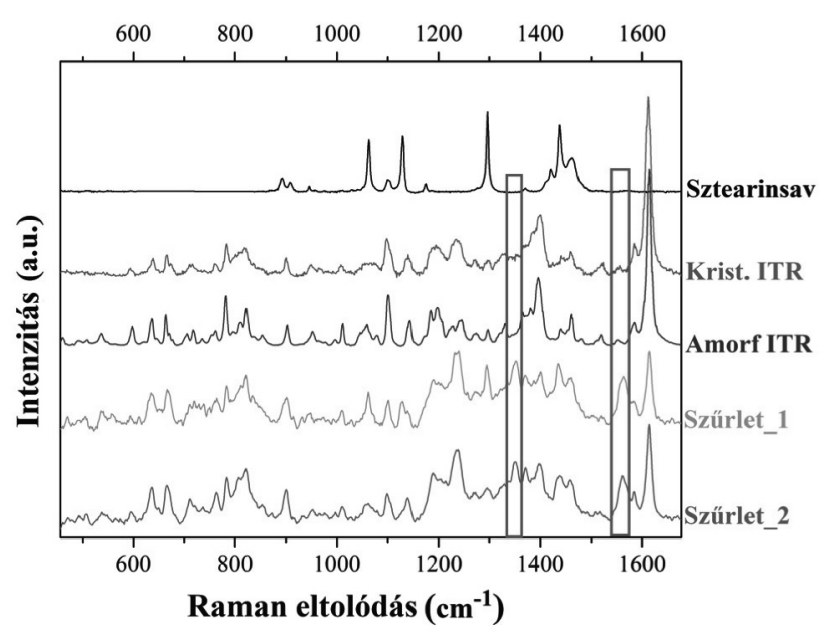

10. ábra: Sztearinsav, amorf és kristályos ITR, illetve a szürlet két véletlen pontjának Raman spektruma. Piros téglalapokkal kiemelve két példa ismeretlen, nem asszignálható csúcsokra.

A sztearinsav és a hatóanyag hidrogén-kötés által stabilizált adduktja a kiindulási anyagok hidrofób jellege miatt oldhatatlan lesz a közegben. A MgSt tehát közvetve oldhatatlan adduktképzés útján csökkenti az amorf ITR kioldódását. A korábban említett lubrikáns csere mellett egy másik járható út a tabletta kioldódás növelésére, ha a kezdeti ASD-mátrixot (PVPVA64) a hatóanyaggal H-kötések kialakítására képes polimerrel (hidroxipropil-metilcellulóz, HPMC) helyettesítjük (11. ábra). Ily módon a hatóanyag stabilizálódik a másodrendü kötés által és nem képzi a szóban forgó adduktot.

\section{Hivatkozások}

[1] C. A. Lipinski, Journal of Pharmacological and Toxicological Methods 2000, 44, 235-249. https://doi.org/10.1016/S1056-8719(00)00107-6

[2] G. L. Amidon, H. Lennernäs, V. P. Shah, J. R. Crison, Pharmaceutical Research 1995, 12, 413-420. https://doi.org/10.1023/A:1016212804288

[3] T. Takagi, C. Ramachandran, M. Bermejo, S. Yamashita, L. X. Yu, G. L. Amidon, Molecular Pharmaceutics 2006, 3, 631-643 https://doi.org/10.1021/mp0600182

[4] M. S. Ku, W. Dulin, Pharmaceutical Development and Technology 2012, 17, 285-302. https://doi.org/10.3109/10837450.2010.535826

[5] W. L. Chiou, S. Riegelman, Journal of Pharmaceutical Sciences 1971, 60, 1281-1302. https://doi.org/10.1002/jps.2600600902

[6] Z. K. Nagy, A. Balogh, B. Démuth, H. Pataki, T. Vigh, B. Szabó, K. Molnár, B. T. Schmidt, P. Horák, G. Marosi, G. Verreck, I. Van Assche, M. E. Brewster, International Journal of Pharmaceutics 2015, 480, 137-142. Https://doi.org/10.1016/j.ijpharm.2015.01.025

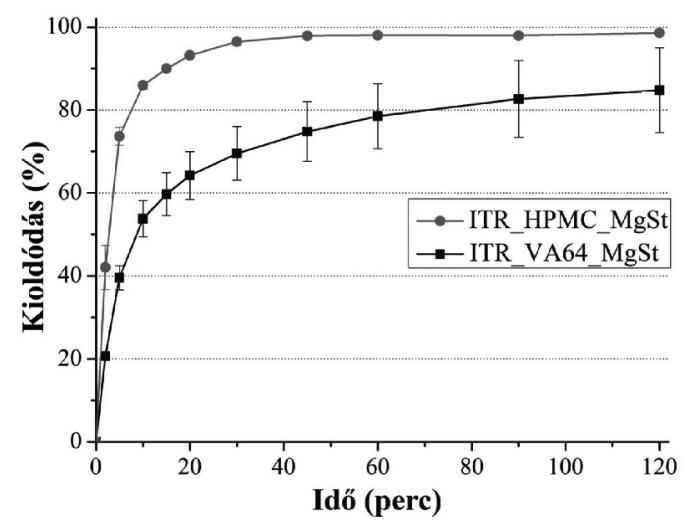

11. ábra: Különböző ASD-mátrixú tabletták kioldódási profilja. Paraméterek: 1sd. 3. ábra.

Ebben a munkában bemutattam, hogy az elektrosztatikus szálképzés egy jó alternatívája lehet a porlasztva szárításnak amorf szilárd diszperziók előállítására. Az elöállított nanoszálas diszperziók továbbalakítása filmbevont tablettákká direkt préseléssel lehetségesnek tünik. A rossz vízoldhatóságú ITR-ból megvalósítható egy azonnali kioldódású tabletta előállítása, melyben a hatóanyag fizikailag és kémiailag is stabil.

\section{Köszönetnyilvánítás}

A szerző köszönettel tartozik a következő személyeknek a segítségükért: Nagy Zsombor Kristóf témavezető, Marosi György konzulens, Farkas Attila, Balogh Attila, Kiserdei Éva, Geert Verreck, Johny Bertels, Vigh Tamás, Pataki Hajnalka, Nagy Brigitta, Madarász János, Nagygyörgy Viola, Tábi Tamás, Vágó Emese, Kemény Sándor, Demeter Ádám, Hoffmanné Szalay Zsófia, Szabó Edina, Galata Dorián és a kutatócsoport tagjai.

[7] B. Démuth, A. Farkas, H. Pataki, A. Balogh, B. Szabó, E. Borbás, P. L. Sóti, T. Vigh, É. Kiserdei, B. Farkas, J. Mensch, G. Verreck, I. Van Assche, G. Marosi, Z. K. Nagy, International Journal of Pharmaceutics 2016, 498, 234-244. https://doi.org/10.1016/j.ijpharm.2015.12.029

[8] International Conference on Harmonization, Q8 Guideline Pharmaceutical Development, 2009.

[9] B. Démuth, A. Farkas, B. Szabó, A. Balogh, B. Nagy, E. Vágó, T. Vigh, A. P. Tinke, Z. Kazsu, Á. Demeter, J. Bertels, J. Mensch, A. Van Dijck, G. Verreck, I. Van Assche, G. Marosi, Z. K. Nagy, Advanced Powder Technology 2017, 28, 1554-1563. https://doi.org/10.1016/j.apt.2017.03.026

[10] B. Démuth, A. Farkas, A. Balogh, K. Bartosiewicz, B. Kállai-Szabó, J. Bertels, T. Vigh, J. Mensch, G. Verreck, I. Van Assche, G. Marosi, Z. K. Nagy, Journal of Pharmaceutical Sciences 2016, 105, 2982-2988. https://doi.org/10.1016/j.xphs.2016.04.032

[11] B. Démuth, D. L. Galata, E. Szabó, B. Nagy, A. Farkas, A. Balogh, E. Hirsch, H. Pataki, Z. Rapi, L. Bezúr, T. Vigh, G. Verreck, Z. Szalay, Á. Demeter, G. Marosi, Z. K. Nagy, Molecular Pharmaceutics 2017, 14, 3927-3934. https://doi.org/10.1021/acs.molpharmaceut.7b00629 


\section{Investigation of downstream processing of electrospun amorphous solid dispersion}

Appearance and intense spreading of poorly soluble drugs in drug discovery pipelines stimulate the introduction of new types of formulations that enable higher bioavailability than the original, crystalline active pharmaceutical ingredient. Amorphous solid dispersions (ASDs) usually contain a water-soluble polymer matrix and a drug with weak solubility. Besides other technologies, electrostatic spinning is emerging as a promising technique to produce ASDs with advantageous, extremely fast dissolution owing to the fibrous structure and high surface area. However, products containing electrospun ASDs are not on the market yet due to the lack of proper scaling up of this technology and downstream processing of the obtained materials. This work aimed to present a newly developed, scaled-up electrospinning technology called high speed electrospinning and a possible downstream processing of the fibrous ASD to generate film-coated tablet formulation.

High speed electrospinning applies electrostatic and centrifugal forces to generate fibers. During this work, ASD of itraconazole (ITR) and vinylpyrrolidon-vinyl acetate copolymer (PVPVA64) was investigated. Compared to spray drying, in course of electrospinning it is possible to work with much more concentrated solutions, hence, the amount of the evaporated organic solvent is much less. Based on our estimations, high speed electrospinning can meet the requirements set up by the pharmaceutical industry. Nanofibers prepared by this technology were similar to those obtained by the small-scale, single needle version and stabilities of the two ASDs were analogous. In case of ASDs, the largest challenge can be their physical stability as the amorphous drug is prone to crystallize over storage. ITR did not crystallize over a year of storage at $25{ }^{\circ} \mathrm{C} / 60 \%$ relative humidity and its dissolution profile remained the same.

Tableting was studied with a design of experiment approach. Direct compression was intended to be applied. After sieving the electrospun material on a $0.8 \mathrm{~mm}$ sieve, it was blended with conventional excipients like mannitol, microcrystalline cellulose, crospovidone, silicium-dioxide and magnesium stearate. It was feasible to produce tablets with low disintegration time and high tensile strength on a compaction simulator. Furthermore, with an optimized composition rotary press tableting could also be performed and tablets with appropriate hardness, disintegration time and weight variation were obtained. According to the literature, this kind of tableting approach to produce immediate-release tablets containing nanofibrous ASD has never been studied.

Film coating can be considered as a risky step concerning ASDs. Water acts as a plasticizer lowering the glass transition temperature, whereby possibly deteriorating the stability. As it was mentioned, the pure ASD showed good stability at $25{ }^{\circ} \mathrm{C} / 60 \%$ relative humidity. Tableting did not change this behavior, as tablets released ITR in the same way after one year of storage at $25{ }^{\circ} \mathrm{C} / 60 \%$ relative humidity. Furthermore, significant chemical degradation did not occur during this period.

When tablets containing the aforementioned excipients and the nanofibers were exposed to in vitro dissolution test, a significant decrease (15-25\%) in dissolution was observed in comparison with the pure ASD. As it turned out, magnesium stearate $(\mathrm{MgSt})$ added to the tablet as a lubricant decreases the dissolution extent. In the acidic medium, stearic acid is formed from MgSt, which has a low solubility but is able to form ITR-stearate adduct, which is insoluble in the aqueous medium. This adduct is stabilized by a hydrogen bond formed between triazole group of the drug and the stearic acid. However, by application of another lubricant, sodium stearyl fumarate, this phenomenon could be avoided and $>95 \%$ dissolution was achieved. Another possible solution is to perform the electrospinning process with hydroxypropyl methylcellulose (HPMC). HPMC is able to form hydrogen bonds with ITR and stabilize it this way. If this ASD is converted into table formulation, $100 \%$ of dissolution extent can be accomplished in spite of the presence of MgSt.

In this work, it was shown that electrostatic spinning is a promising alternative for spray drying as a solvent-based approach to produce ASDs. The obtained electrospun material can be formulated to tablets via direct compression and afterwards film-coating can be performed. Thus, the poorly soluble ITR can be incorporated into a physically and chemically stable, immediate-release tablet formulation. 